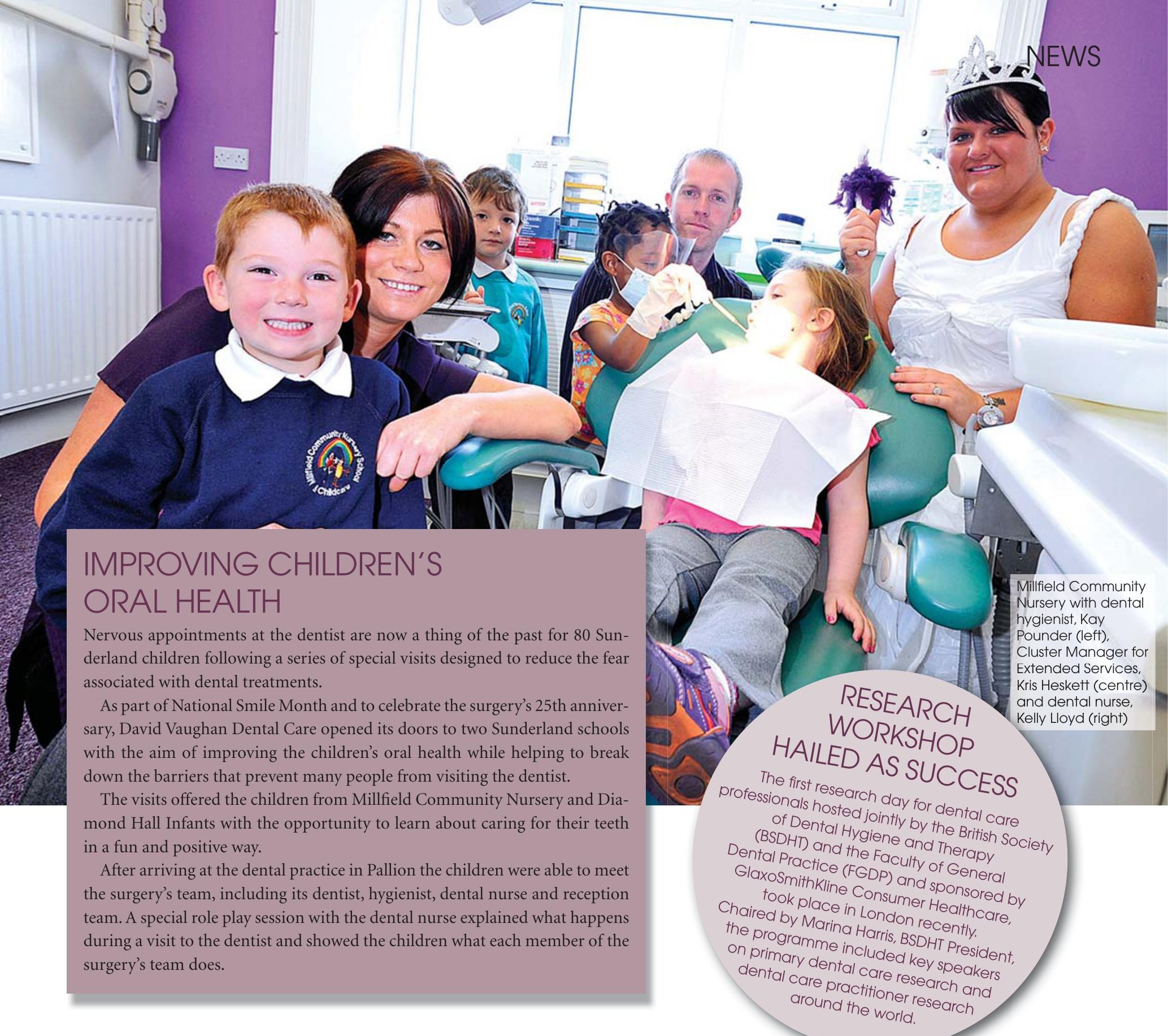

\title{
UNIVERSITY OF KENT FIRST YEAR STUDENTS GAIN DISTINCTIONS
}

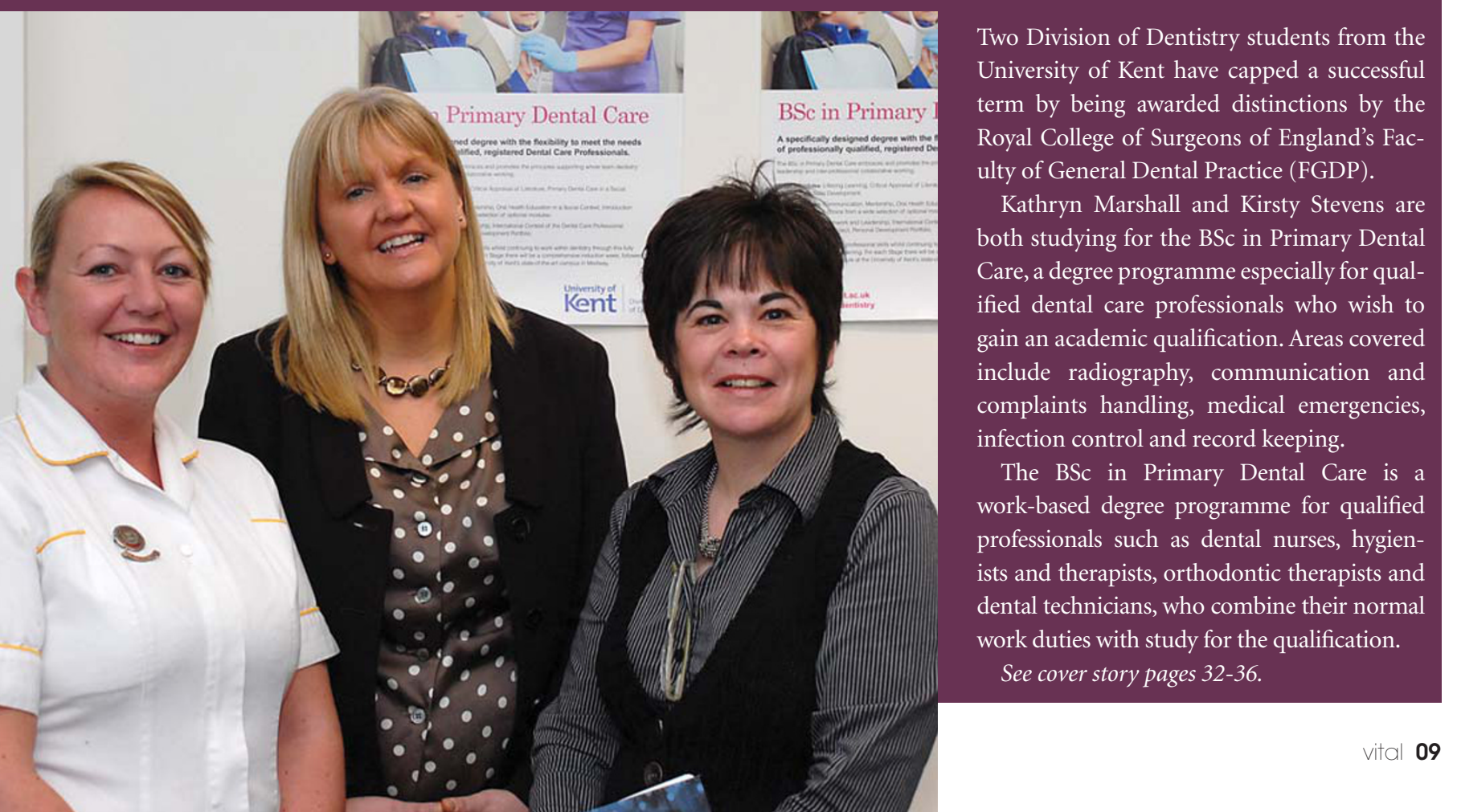

